\section{Comparison of economic loss between generic drug and patent drug in stock-out and stagnant condition at Surabaya Islamic Hospital, Indonesia}

\author{
Thinni Nurul Rochmah, ${ }^{1}$ \\ Dwi Ratnasari, ${ }^{2}$ Hanin Dhany Robby ${ }^{3}$ \\ ${ }^{1}$ Department of Health Policy and \\ Administration, Faculty of Public \\ Health, Universitas Airlangga, \\ Surabaya; ${ }^{2}$ WJP Consultant, Surabaya; \\ ${ }^{3}$ Faculty of Public Health, Universitas \\ Airlangga, Surabaya, Indonesia
}

\begin{abstract}
The condition of stagnant and stock-out might cause economic loss and indicate ineffective and inefficient drug inventory management in the hospital. This study aims to compare the economic loss between generic drug and patent drug in stagnant and stock-out condition at Surabaya Islamic Hospital. The research was observational descriptive with cross-sectional design. The study was conducted with sample of 148 generic drugs and 299 patent drugs at pharmacy unit, Surabaya Islamic Hospital. The data was analyzed using independent t-test. The result showed different stagnant and stock put (p-value) experience in drug inventory between generic drug $(70 \%)$ and patent drug $(30 \%)$. The t-test in economic loss showed no difference between generic drug and patent drug stagnant ( $\mathrm{p}$ value $=0.75)$ and stock-out $(p$-value $=0.86)$ experience. The economic loss of generic drug experienced stagnant and stock-out in July-December 2015 with the amount up to IDR $86,476,696$, while patent drug experienced loss both stagnant and stock-out up to IDR 88,349,589 in October 2016-March 2017. The study concluded that both conditions were disadvantageous for hospital's revenue and inventory management.
\end{abstract}

\section{Introduction}

The management of clinical pharmacy plays an important part on the hospital's revenue. Therefore, pharmacy logistic must be organized carefully and with full of responsibility in order to be efficient and effective. ${ }^{1}$ The problem occurred in pharmacy logistic is the incident of stagnant and stock out. Stagnant is a condition in which the amount of left over medication at the end of the month is three times more than the average. ${ }^{2,3}$ Stock-out is defined as the condition in which the amount of left over medication at the end of month is less from the average or out of stock..$^{4,5,6}$ Either stagnant or stock-out in clinical pharmacy could cause economic loss such as purchasing cost, ordering cost, holding cost of stagnant medication, and opportunity cost for stock out medication. ${ }^{3}$

Hospital is a health care which carries out health service for individual comprehensively including hospitalization, outpatient, and emergency care unit. ${ }^{1,7}$ Surabaya Islamic Hospital uses two types of drug, those are generic and patent in its clinical pharmacy. Generic drug is used as much as $70 \%$ for the patients of national health insurance (the healthcare and social security agency), while patent drug is used as much as $30 \%$ for the general patients without insurance. Hospital had found the problem of stagnant and stock out since 2015 in both generic and patent drugs. Its clinical pharmacy mentioned that generic drug was stagnant by $13.5 \%$ during July-December 2015, while the stock out condition was by $56 \%$ with the average of 83 stock-out drug items every month. Meanwhile, patent drug experienced stagnant condition by $26.4 \%$ with the average of 79 stagnant drug items every month and was in stock out by $28 \%$ with the average of 84 stock-out drug items every month.

Stagnant and stock-out in pharmacy logistic affect hospital budget. Such stagnant and stock out condition might lead to any loss for the hospital, particularly the medication supply. ${ }^{7}$ Therefore, the condition needs effective and efficient inventory management in order to prevent the condition of stagnant and stock out. This research aims to analyze and compare the economic loss from stagnant and stock out condition to both generic and patent drug at clinical pharmacy of Surabaya Islamic Hospital.

\section{Materials and Methods}

This study was descriptive and observational research using cross sectional design. The research was conducted to 148 generic medications and 299 patent medications during July 2015 until March 2017 at clinical pharmacy of Surabaya Islamic Hospital. We observed the pharmacy logistic without giving any intervention and interview to pharmacy staffs except the Head of Clinical Pharmacy. The study analyzed the data, by collecting it from the document of clinical pharmacy, using independent sample t-test to compare the economic loss between the patent and generic medication in both stagnant and stock-out condition.
Correspondence: Thinni Nurul Rochmah, Department of Health Policy and Administration, Faculty of Public Health, Universitas Airlangga, Jl. Mulyorejo, Surabaya, Jawa Timur 60115, Indonesia.

Tel. +62.31.5920948, 5920949 -

Fax: +62.31 .5924618 .

E-mail: thinni_nurul@ffkm.unair.ac.id

Key words: economy loss, generic drug, patent-drug, stock-out.

Acknowledgments: the authors would like to thank Surabaya Islamic Hospital for the approval to be the study setting on the research.

Contributions: DR, data collecting, analysing, references search; HDR, manuscript writing; TNR, data analysing manuscript reviewing and references search.

Conflict of interests: the authors declare no potential conflict of interests.

Funding: none.

Clinical trials: this study didn't involve any clinical trials.

Conference presentation: part of this paper was presented at the $3^{\text {rd }}$ International Symposium of Public Health, 2018 October 31 - November 1, Universitas Airlangga, Surabaya, Indonesia.

Dedication: the article is dedicated to Surabaya Islamic Hospital on the occasion of improvement of drug logistics management.

Received for publication: 28 July 2019.

Revision received: 9 September 2019.

Accepted for publication: 15 October 2019.

This work is licensed under a Creative Commons Attribution NonCommercial 4.0 License (CC BY-NC 4.0).

${ }^{(C)}$ Copyright: the Author(s), 2019

Licensee PAGEPress, Italy

Journal of Public Health in Africa 2019; 10(s1):1169 doi:10.4081/jphia.2019.1169

\section{Results}

The study indicated stagnant condition towards generic medication based on pharmacy logistic document during July December 2015 with the amount of 136,689 medications. The generic medication also experienced stock out with the amount of 203,213 medications. Both the conditions in generic drug caused loss in economic value of IDR 86,476,696 for Islamic Hospital Surabaya. Stagnant condition towards 
patent medication in pharmacy logistic occurred in October 2016 - March 2017 with the amount of 76,254 medications, while stock out condition ran out 50,855 patent medications. The economic loss from those conditions in patent medication was IDR $88,349,589$ for the hospital.

There was difference of medication inventory between generic and patent medication in both condition of stagnant and stock out (Table 1). The highest stagnant condition was showed by mean value in generic medication, while the highest stock out condition was from patent medication. Otherwise, in economy loss, there was no difference between patent and generic medication both stagnant and stock out condition (Table 2).

The economic loss from stagnant condition was incurred by holding cost and ordering cost of stagnant medication. Meanwhile, the stock out caused loss in opportunity cost. The loss from patent medication in stagnant was higher than generic medication by IDR $10,319,122$ which was incurred by ordering cost and holding cost consisted of expired cost, electrical cost, and investment cost. In addition, the patent medication was also the highest loss in stock out condition by IDR 29,608,207 due to the opportunity cost and opportunity lost.

According to an interview with the Head of Clinical Pharmacy, the planning implementation used manual and visual counting the stock medication. The pharmacy staffs did not plan based on the medication consumption trends. The head also stated that the clinical pharmacy did not use any special method to control the stock. Besides, the hospital information system did not show all of supplies for the pharmacy staffs to plan based on the consumption pattern.

\section{Discussion}

When the pharmacy logistic experienced stagnant and stock out condition, the hospital was in economic loss due to the purchasing cost, ordering cost, and holding cost. ${ }^{1,8}$ The system of pharmacy management becomes ineffective if those unwanted conditions, stagnant and stock out, had frequently occurred in clinical pharmacy. The longer and the more frequent the clinical pharmacy was in stock out and stagnant condition, the less effective the unit managed its pharmacy logistic. ${ }^{9}$

The economic loss from patent medication was bigger than the generic medication because sale and utilization from generic was more than patent for medical prescription. Drug types were the same; these two remained to obtain the evaluation of inventory management. Therefore, the purchase cost and ordering cost for generic was more than patent. Even the loss from both of stagnant caused the hospital to expense expired medication and broken items during inventory. ${ }^{10}$

Excessive investment for clinical pharmacy would increase holding cost which likely had contained opportunity cost. ${ }^{11}$ The holding cost for generic and patent experienced stagnant was obtained from investment cost and electrical cost for every stagnant medication which was kept in inventory. ${ }^{12}$ Stagnant in the pharmacy also indicated the wasted purchasing cost. ${ }^{13}$ In addition, stagnant caused loss of ordering cost which was obtained from cost of administration and phone to order the medication.

The loss from stagnant was due to holding cost to stock in the inventory. The stock which was kept for long time would increase the risk of damaged and expired medication. This condition was caused by the plan that was not based on consumption of medication. ${ }^{14}$ If the order was made a lot of stocks and the consumption was little, this condition also caused stagnant for clinical pharmacy. 15

Generic and patent medication experienced stock out would cause loss of opportunity cost. The loss of opportunity cost means that the hospital would be profit loss and not obtain revenue due to the medications which were in stock out. The generic medications experienced stock out more than the patent medication at Surabaya Islamic Hospital because the demand for generic from patients used national health insurance was higher than patients without insurance. Besides, the national health insurance has required generic medication for their customer in all of hospital and clinics. The clinical pharmacy managed stock out condition by purchasing some medications from outside or by giving the prescription to patients to buy the medication outside the hospital in order to meet the patients' need.

The consumption trend depends on various disease trends likely occurred, thus the stagnant and stock out as the requirement for medication would be different every month and could not be same as the planned stock.16 The planning was the key in management. ${ }^{17}$ The implementation of planning might avoid the stock out in pharmacy by using proper methods and determined basic planning such as consumption, epidemiology, combination method that adjusted with available budget. ${ }^{18}$

Controlling the supplies is an activity to monitor and to manage optimum stocks in order to fulfill the need of number, quality, and time with low cost. ${ }^{1}$ Controlling via computer would be good for the clinical pharmacy but they experienced lack access of hospital information system to pharmacy data. The situation limited the staffs to analyze the data of stocks and required medication. If the clinical pharmacy managed the stock properly according to the information, the inventory management would be timely, accuracy, reliable and consistent. ${ }^{19}$

The cause of stagnant and stock out was known from ineffective and inefficient management. ${ }^{20}$ The hospital should improve the inventory management for both generic and patent drugs whereby in stagnant and stock out condition because both

Table 1. The independence T-test of medication inventory between generic medication and patent medication in stagnant and stock out condition.

\begin{tabular}{lcccc} 
Condition & Drug Types & Mean & Standard Deviation & P \\
\multirow{2}{*}{ Stagnant } & Generic & 19.67 & 5.08593 & 0.00 \\
& Patent & 55.4 & 3.50714 & \\
Stock-out & Generic & 83 & 5.72713 & 0.00 \\
& Patent & 141.6 & 4.50555 & \\
\hline
\end{tabular}

Table 2. The independence T-test of economic loss between the generic medication and the patent medication in stagnant and stock out condition.

\begin{tabular}{llccccc} 
Condition & $\begin{array}{l}\text { Drug } \\
\text { Types }\end{array}$ & $\begin{array}{c}\text { Minimum } \\
\text { (IDR) }\end{array}$ & $\begin{array}{c}\text { Maximum } \\
\text { (IDR) }\end{array}$ & $\begin{array}{c}\text { Mean } \\
\text { (IDR) }\end{array}$ & $\begin{array}{c}\text { Standard Deviation } \\
\text { (IDR) }\end{array}$ & P \\
Stagnant & Generic & 0 & $14,151,796$ & $690,6070.25$ & $7,237,495.483$ & 0.75 \\
& Patent & 24,315 & $39,495,525$ & $10,319,122.00$ & $19,455,157.00$ & \\
\multirow{2}{*}{ Stock out } & Generic & 0 & $59,216,414$ & $23,536,550.00$ & $1,680,550.59$ & 0.86 \\
& Patent & $11,653,210$ & $35,419,890$ & $29,608,207.00$ & $41,872,327.90$ & \\
\hline
\end{tabular}


drug types have equivalent priority to be improved. Detailed recommendations to improve the inventory management are as follows:

1. Improving the planning by considering the drugs consumption which is adjusted to the disease trends in the hospital. One of the methods that can be used for the generic and patent medications was MMSL (Minimum - Maximum Stock Level), a method to invent the drugs by scheduled purchasing and regulated ordering interval.

2. Writing the report of drug consumption which was adjusted to disease trends to identify the priority of each drug every month.

3. Determining safety stock for each medication as controlling to minimize the stagnant and stock out condition.

4. Improving the hospital information system ${ }^{14}$ by giving easy access and recent data that can be used to analyze medication consumption trends. In addition, it would be beneficiary for the staffs to plan the inventory based on data from hospital information system.

\section{Conclusions}

The study concludes that inventory management at clinical pharmacy of Surabaya Islamic Hospital was not efficient and effective as there was stagnant and stock out condition which frequently happened both in generic and patent drugs. There was difference of drugs inventory between patent and generic in both of stagnant and stock out condition, but there was no difference of economic loss between the generic and patent in same conditions. The economic loss was incurred by stagnant and stock out condition that affect the holding cost, ordering cost, opportunity cost. We recommended improving the hospital information system, writing the report of consumption adjusted to disease trends, improving drug-planning system by using certain method, and determining the safety stock.

\section{References}

1. Aditama. Manajemen Administrasi Rumah Sakit. Jakarta: Universitas Indonesia; 2003.

2. Khasanah U. Analisis Manajemen Logistik Obat dalam Perencanaan, Pengendalian Persediaan, Safety Stock, dan Reorder Point. Universitas Airlangga; 2010.

3. Muzakkin M. Analisis Kerugian yang Ditanggung oleh RSUD Dr. Soetomo Surabaya Sebagai Akibat Dari Stagnant dan Stockout Obat (Studi Kasus di Unit Logistik Medik Instalasi Farmasi). Universitas Airlangga; 2008.

4. Hadidah IS. Analisis Kerugian Akibat Kejadian Obat Stagnant Dan Stockout Di Instalasi Farmasi (Studi di UPT Rumah Sakit Mata Masyarakat Jawa Timur). Universitas Airlangga; 2016.

5. Pudjiraharjo WJ. Manajemen Logistik. Surabaya: Airlangga University Press; 2015.

6. Waluyo DS. Analisis Penyebab Utama Stagnant Pada Manajemen Persediaan Obat di Rumah Sakit Kusta Kediri. Universitas Airlangga; 2006.

7. Mellen RC, Pudjiraharjo WJ. Faktor Penyebab dan Kerugian Akibat Stockout dan Stagnant Obat Di Unit Logistik RSU Haji Surabaya. J Adm Kesehat Indones [Internet]. 2013;1(1). Available from: http://journal.unair.ac.id/downloadfull/J AKI4825-c31bc95728fullabstract.pdf

8. Yamit S. Manajemen Persediaan. Yogyakarta: EKONISIA Fakultas Ekonomi UI; 2003.

9. Quick DJ. Managing Drug Supply, the Selection, Procurement, DIstribution, and Uses of Pharmaceuticals. Massachusetts: Kumarianpress Inc.; 1997.

10. Ingersoll BK. Chapter 6 : Inventory Management for the Pharmacy Technician. In: Accreditation Council of Pharmacy Education. 2017. p. 53-66. 11. Rangkuti F. Manajemen Persediaan
Aplikasi di Bidang Bisnis. Jakarta: PT Raja Grafindo Persada; 2004.

12. Clemons EK, Row M. McKesson drug company-a case study of Economost: a strategic information system. Proc Twenty-First Annu Hawaii Int Conf Syst Sci 1988 VolIV Appl Track [Internet]. 2018;5(1):141-9. Available from: http://ieeexplore.ieee.org/document/11973/

13. Mellen R, Pudjirahardjo W. Faktor Penyebab dan Kerugian akibat Stockout dan Stagnant Obat di Unit Logistik RSU Haji Surabaya. J Adm Kesehat Indones 2013.

14. Leung NHZ, Chen A, Yadav P, Gallien J. The impact of inventory management on stock-outs of essential drugs in subSaharan Africa: Secondary analysis of a field experiment in Zambia. PLoS One 2016;11(5):1-18.

15. Kumalasari A. Pengendalian Persediaan Obat Generik Dengan Metode MMSL (Minimum-Maximum Stock Level) dan Metode EOQ (Economic Order Quantity) (Studi di Unit Farmasi Rumah Sakit Islam Surabaya). Universitas Airlangga; 2016.

16. Ratnasari D. Analysis Jumlah Kerugian Ekonomi Akibat Kejadian Stagnant Dan Stockout Obat Paten Di Rumah Sakit Islam Surabaya. Universitas Airlangga; 2017.

17. Bowersox DJ. Supply Chain Logistics Management. Boston: Brent Gordon; 2002.

18. Kementrian Kesehatan Republik Indonesia. Peraturan Menteri Kesehatan Republik Indonesia Nomor 58 Tahun 2014 Tentang Standar Pelayanan Kefarmasian di Rumah Sakit. Jakarta; 2014.

19. Viale JD. Basics of Inventory Management: From Warehouse to Distribution Center. US: Axzo Press; 1996.

20. Mewse D. Keeping an eye on the health of your business. SA Pharm J. 2011;78(10):13-5. 